\title{
Acceptance of Toddler Nutrition Decision Support Systems Using the Technology Acceptance Model (TAM) Method
}

\author{
Gamasiano Alfiansyah ${ }^{1}$, Mudafiq Riyan Pratama ${ }^{2}$, Selvia Juwita Swari ${ }^{3 *}$ \\ ${ }^{1,2,3}$ Health Department, Politeknik Negeri Jember, Indonesia \\ ${ }^{*}$ Corresponding author. Email: selvia@polije.ac.id
}

\begin{abstract}
One of the Sustainable Development Goals (SDGs) is terminating the malnutrition 1n 2030. Stunting is malnutrition due to lack of nutritional intake for a long time due to feeding that does not match nutritional needs. The toddler nutrition decision support system was created to help parents of toddlers and health cadres to perform early detection of stunting. The researchers intend to obtain an overview of the level of acceptance of the stunting early detection system by residents of the village of Kemuning Lor, Jember Regency. This research was descriptive research, and the number of these community was 20 people who are village officials. Data analysis was conducted through scoring and presented in tables and percentages. The results showed that the level of system acceptance based on the perceived usefulness aspect had the highest value $89.75 \%$, variable perceived ease of use $87,08 \%$, variable behavioral intention to use $86,25 \%$, variable attitude toward using $85,94 \%$. It can be concluded that the community accepts stunting early detection system technology because the system is simple to use and the community feels the benefits. The development of an early stunting detection system is still needed as an effort to reduce stunting cases.
\end{abstract}

Keywords: Stunting, TAM, Early Detection

\section{INTRODUCTION}

One of the Sustainable Development Goals (SDGs) is to end all forms of malnutrition in 2030. Stunting is an issue of malnutrition due to lack of nutritional consumption for a long time due to the arrangement of food that does not match dietary needs. This causes the death of children and infants, and when they grow up, these children do not have maximum body posture [1]. Jember is a regency with increased cases of stunting in East Java [2][3][4].

The government has implemented the Movement of HPK (the First 1000 Days of Life) as an effort to avert stunting [5], [6]. However, the program has not run well due to the mother's lack of knowledge, need more infrastructure, and need more human resources [6][7][8]. Toddlers are a group that is vulnerable to stunting so they need to get attention from parent so they don't suffer from stunting [9]. Stunting is dangerous for toddlers because it will increase the risk of morbidity and mortality, and inhibiting the motor and mental growth of toddlers [10].
Stunting in toddlers is caused by age, gender, household economic factors, maternal education, and body mass index, early marriage age, fetal growth, childcare, chronic infectious diseases, and the environment [11][12][13][14][15][16][17][18][19][20].

Determination of the nutritional status of toddlers is carried out to improve the health status of toddlers. Health workers use the "Kartu Menuju Sehat (KMS)" to ascertain the nutritional status of toddlers. The disadvantage of KMS is that it requires more accuracy to be precise in drawing the nutritional status line of toddlers, can only be used to determine nutritional status every month without providing information on growth and development of the toddler at any time, and without providing information about the food needed for toddlers [9]. One of the root causes of nutritional problems is the lack of use of technology [21].

Based on these problems, the researchers have designed a web-based decision support system that can be used by parents to determine the nutritional status of toddlers as an effort to prevent and detect stunting early. 
This web-based system can be accessed through http://gizi.desakemuninglor.id/.

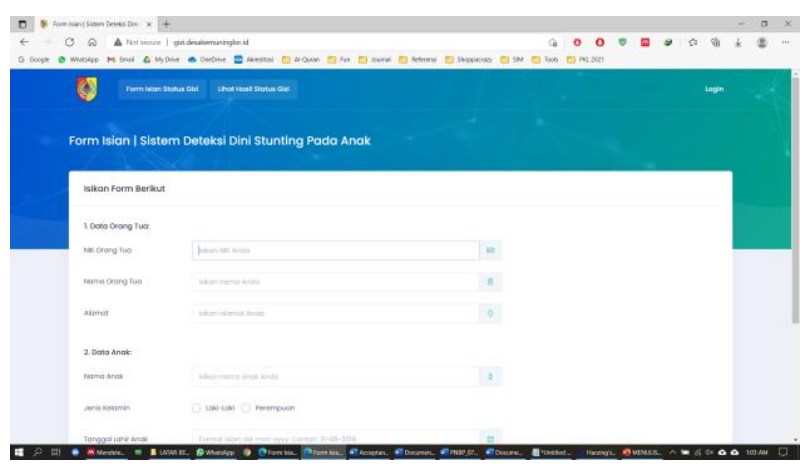

Figure 1. Web-based Stunting Early Detection System

The system has been implemented in the community service activity program as a dissemination of research results. The program targets were village officials and health cadres so that they can disseminate to the community in the village. The researcher intend to describe the level of acceptance the stunting early detection system by the community.

\section{RESEARCH METHOD}

This research was a descriptive that aimed to provide an overview of the level of acceptance of the stunting early detection system. Descriptive research is research that aims to investigate an event or condition and the results are presented in a research report [22]. This research was conducted at the village hall of Kemuning Lor Village, Jember. The variables of this research were perceived ease of use, perceived usefulness, attitude toward using, and behavioral intention to use.

The population of this study was 20 people who were village officials and health cadres of Kemuning Lor Village. Data was collected using a questionnaire given to 20 community. Data analysis was carried out through four stages consisting of data entry, data checking, scoring, and drawing conclusions. Scoring was carried out using a Likert scale of 1-4 with criteria $1=$ strongly disagree, $2=$ disagree, $3=$ agree, $4=$ strongly agree. The conclusions were drawn with the criteria of $0-25 \%=$ very poor, $25.01-50 \%=$ poor, $51.01-75 \%=$ good, $75.01-100 \%$ $=$ very good.

\section{RESULTS}

Stunting is a chronic malnutrition issue caused by deficient nutritional intake for a long time due to feeding that is not in accordance with the required nutrition. Stunting can make children vulnerable to illness, and can cause death in children and infants [1]. Children who experience stunting during their toddler years will have low cognitive levels and poor psychosocial behavior [23]. Therefore, an early detection system that capable to detect stunting in children is needed.
Researchers have created a website-based stunting early detection system as an effort to help the community identify stunting and reduce stunting in the community. The web-based system can be accessed through http://gizi.desakemuninglor.id/. The system had been socialized and implemented to the villagers of Kemuning Lor Village, Jember. Therefore, it was necessary to evaluate the level of acceptance of the system by the community.

Perceived ease of use is a level that describes the public's perception that the system is easy to be used and the system can help health cadres complete work more easily for early detection of stunting. Indicators of perceived ease of use include systems that are easy to understand, easy to use, controllable, and flexible [24], [25]. The results of the study are shown in the table.

Table 1. Perceived Ease of Use Variable

\begin{tabular}{|c|c|c|c|c|c|c|c|c|}
\hline \multirow{2}{*}{$\begin{array}{l}\text { Perceived } \\
\text { Ease of Use }\end{array}$} & \multicolumn{6}{|c|}{ Question } & \multirow[t]{2}{*}{ Sum } & \multirow[t]{2}{*}{$\%$} \\
\hline & 1 & 2 & 3 & 4 & 5 & 6 & & \\
\hline $\begin{array}{l}\text { Strongly } \\
\text { disagree }\end{array}$ & 0 & 0 & 0 & 0 & 0 & 0 & 0 & 0 \\
\hline Disagree & 0 & 0 & 0 & 0 & 0 & 0 & 0 & 0 \\
\hline Agree & 7 & 8 & 15 & 10 & 10 & 12 & 62 & $51.67 \%$ \\
\hline $\begin{array}{l}\text { Strongly } \\
\text { agree }\end{array}$ & 13 & 12 & 5 & 10 & 10 & 8 & 58 & $48.33 \%$ \\
\hline
\end{tabular}

The results showed that $0 \%$ of community stated strongly disagree, $0 \%$ of community said they disagreed, $51.67 \%$ of community agreed, and $48.33 \%$ of community stated strongly agree that system was simple to use. Based on the results of scoring using a Likert scale, the total score is 418 . The total score needs to be interpreted whether the system is categorized as very poor, poor, good, or very good using score percentage. Score percentage is calculated using the formula total score: highest total score $\mathrm{x} 100 \%$. With these calculations, the results obtained that the percentage score is $87.08 \%$. So the system is accessible to use by the community.

Perceived ease of use of the system is a measure that users believe that the system is easy to understand and easy to use [24], [26]. The stunting early detection system is very easy to use. Users only need to enter parental data (parent's name, population identification number, and address) and child's data (name, gender, date of birth, and child's height). This proved that the use of the system was not because of social pressure, but because the system was simple to use.

Ease of use will diminish the time and attempt of users in learning the system. Users admit that a system that is easy to understand, more flexible, and simple to operate as characteristics of ease of use. The results indicated that the perceived convenience factor was proven to be able to interpret a community's reasons for adopting the system. It also explained that the new system established by researchers could be accepted by users. Several barometers of the ease of use of the system: 
(1) the system is very simple to accomplished; (2) the system does efficiently what the user needs; (3) very simple to improve user expertise; (4) the system is very simple to managed [24].

Perceived usefulness describes the level of public perception about the benefits of using the stunting early detection system. The indicator of perceived usefulness variable are the usefulness and benefits [27].

Table 2. Perceived Usefulness Variable

\begin{tabular}{|l|c|c|c|c|c|c|c|}
\hline \multirow{2}{*}{ Perceived Usefulness } & \multicolumn{5}{|c|}{ Question } & \multirow{2}{*}{ SUM } & \multirow{2}{*}{$\%$} \\
\cline { 2 - 7 } & $\mathbf{1}$ & $\mathbf{2}$ & $\mathbf{3}$ & $\mathbf{4}$ & $\mathbf{5}$ & & \\
\hline Strongly disagree & 0 & 0 & 0 & 0 & 0 & 0 & 0 \\
\hline Disagree & 0 & 0 & 0 & 0 & 0 & 0 & 0 \\
\hline Agree & 8 & 9 & 6 & 9 & 9 & 41 & $41.00 \%$ \\
\hline Strongly agree & 12 & 11 & 14 & 11 & 11 & 59 & $59.00 \%$ \\
\hline
\end{tabular}

The results showed that $0 \%$ of community stated strongly disagree, $0 \%$ of community said they disagreed, $41 \%$ of community agreed, and $59 \%$ of community stated strongly agree that the system was that the system provides benefits to users. Based on the results of scoring using a likert scale, the total score is 359. Based on the calculations carried out, the value of the perceived usefulness variable is $89.75 \%$. It can be concluded that the system provides benefits to the community.

Perceived usefulness describes a level where a person trusts that the adoption of a system can enhance the user's work [24]. The stunting early detection system is very beneficial to the community, both to parents and cadres. Parents can check and find out the nutritional status of their children at any time, and for health cadres, the stunting early detection system will facilitate their work because the determination of children's nutritional status is carried out manually.

The usefulness of a system can be assessed from an increase in performance and work performance of users. The analysis of usability is depend on the diversity and prevalence of system use [24], [28]. Individuals will use the system if they realize the advantagess using it [29]. These benefits include (1) make work uncomplicated; (2) effective; (3) raise productivity; (4) enlarge effectiveness; (5) enhance job achievement [30].

Attitude toward using is a description of the community's attitude towards the stunting early detection system that accepts or rejects as the impact when the community uses the system to determine the nutritional condition of their children.
Table 3. Attitude Toward Using Variable

\begin{tabular}{|c|c|c|c|c|c|c|}
\hline \multirow[t]{2}{*}{ Attitude Toward Using } & \multicolumn{4}{|c|}{ Question } & \multirow[t]{2}{*}{ SUM } & \multirow[t]{2}{*}{$\%$} \\
\hline & 1 & 2 & 3 & 4 & & \\
\hline Strongly disagree & 0 & 0 & 0 & 0 & 0 & 0 \\
\hline Disagree & 0 & 0 & 0 & 0 & 0 & 0 \\
\hline Agree & 10 & 11 & 14 & 10 & 45 & $56.25 \%$ \\
\hline Strongly agree & 10 & 9 & 6 & 10 & 35 & $43.75 \%$ \\
\hline
\end{tabular}

The results showed that $0 \%$ of community stated strongly disagree, $0 \%$ of community said they disagreed, $56.25 \%$ of community agreed, and $43.75 \%$ of community stated strongly agree to the use of stunting early detection system. Based on the calculations carried out by researchers, it shows value of attitude toward using variable is $89.75 \%$. It can be concluded that the community accepts the use of the stunting early detection system.

Attitude is one aspect that affects individual behavior, and attitude toward using technology possess an influence on behavioral intention to use [24]. Attitudes towards this behavior are determined by the beliefs obtained about the consequences of a attitude. This belief can enhance attitudes towards behavior based on the evaluation of the data obtained that the behavior can contribute benefits for someone [31].

Behavioral intention to use describes the habit of the community to maintain using the stunting early detection system. The usage rate of a computer system in an individual can be anticipated from the attitude of his interest to the technology, such as motivation to keep using and the desire to drive other users [27].

Table 4. Behavioral Intention to Use Variable

\begin{tabular}{|c|c|c|c|c|c|c|}
\hline \multirow[t]{2}{*}{ Behavioral Intention to Use } & \multicolumn{4}{|c|}{ Question } & \multirow[t]{2}{*}{ SUM } & \multirow[t]{2}{*}{$\%$} \\
\hline & 1 & 2 & 3 & 4 & & \\
\hline Strongly disagree & 0 & 0 & 0 & 0 & 0 & 0 \\
\hline Disagree & 0 & 0 & 0 & 0 & 0 & 0 \\
\hline Agree & 9 & 11 & 12 & 12 & 44 & $55.00 \%$ \\
\hline Strongly agree & 11 & 9 & 8 & 8 & 36 & $45.00 \%$ \\
\hline
\end{tabular}

The results showed $0 \%$ of community stated strongly disagree, $0 \%$ of community said they disagreed, $55 \%$ of community agreed, and $45 \%$ of community stated strongly agree. Based on the results of scoring using a likert scale, the total score is 276. Based on the calculations carried out, it shows that the value of the perceived usefulness variable is $86.25 \%$. It can be concluded that people tend to continue to use the stunting early detection system.

Behavioral intention to use is the behavioral habit of people to continue adopting the technology [24]. Behavioral intention to use is the strength of a person's motive to perform specific behaviors [32]. A person can 
behave a certain behavior or action if he has the intention, interest to perform the behavior. Interest can also indicate an action or behavior that will be carried out in the future and will repeat it in the future [33].

Actual system usage is a actual condition of using the stunting early detection system. Actual system usage is described in the measurement of the number and duration of usage the stunting early detection system. The results of the study are shown in the following table.

Table 5. Actual System Usage Variable

\begin{tabular}{|l|c|c|c|c|}
\hline \multirow{2}{*}{ Actual System Usage } & \multicolumn{2}{|c|}{ Question } & \multirow{2}{*}{ SUM } & \multirow{2}{*}{$\%$} \\
\cline { 2 - 3 } & $\mathbf{1}$ & $\mathbf{2}$ & & \\
\hline Strongly disagree & 0 & 0 & 0 & 0 \\
\hline Disagree & 0 & 0 & 0 & 0 \\
\hline Agree & 9 & 11 & 20 & $50.00 \%$ \\
\hline Strongly agree & 11 & 9 & 20 & $50.00 \%$ \\
\hline
\end{tabular}

The results showed that $0 \%$ of community stated strongly disagree, $0 \%$ of community said they disagreed, $50 \%$ of community agreed, and $50 \%$ of community stated strongly agree. Based on the results of scoring using a likert scale, the total score is 140 . Based on the results of calculations carried out by researchers, it shows that the value of the perceived usefulness variable is $87.50 \%$. It can be concluded that the users agree and believe that the stunting early detection system is easy to use and increases user productivity.

Actual system usage is a actual condition of system usage [24]. Users will be pleased using the system if they admit that the system is easy to use and can raise their productivity, that is reflected in the actual conditions of use [34]. Measurement of actual system usage is the number and duration of time of use of the system. Actual system usage is measured by the amount of time used to interact with the system and the frequency of use of the system [35].

\section{CONCLUSION}

Based on the research that has been carried out, it can be concluded that the community accepts the stunting early detection system because the system is easy to understand, easy to use, and provides benefits for the community in monitoring the nutritional status of children. System development needs to be implemented by adding other features for early detection of other nutritional problems.

\section{AUTHORS' CONTRIBUTIONS}

Gamasiano Alfiansyah carried out research concept, conducting research, and report writing. Mudafiq Riyan Pratama carried out conducting research and data analysis. Selvia Juwita Swari carried out research question and conducting research.

\section{ACKNOWLEDGMENTS}

We sincerely thank Ministry of Education, Culture, Research, and Technology Republic of Indonesia for the funding support (funds supported by PNBP 2021), Kemuning Lor Village, and Politeknik Negeri Jember for funding the research so that this research can be carried out well.

\section{REFERENCES}

[1] MCA Indonesia, Stunting dan Masa Depan Indonesia. Jakarta, 2015.

[2] Dinas Kesehatan Provinsi Jawa Timur, Profil Kesehatan Provinsi Jawa Timur Tahun 2019. Surabaya: Dinas Kesehatan Provinsi Jawa Timur, 2019.

[3] Dinas Kesehatan Provinsi Jawa Timur, Profil Kesehatan Provinsi Jawa Timur 2020. Surabaya: Dinas Kesehatan Provinsi Jawa Timur, 2020.

[4] I. F. Ulfah and A. B. Nugroho, "Menilik Tantangan Pembangunan Kesehatan di Indonesia Faktor Penyebab Stunting di Kabupaten Jember," Sospol J. Sos. Polit., vol. 6, no. 2, pp. 201-213, 2020.

[5] Kementerian Koordinator Bidang Kesejahteraan Rakyat, Kerangka Kebijakan Gerakan Nasional Percepatan Perbaikan Gizi dalam Rangka Seribu Hari Pertama Kehidupan (Gerakan 1000 HPK). Jakarta: Kementerian Koordinator Bidang Kesejahteraan Rakyat, 2013.

[6] D. I. Mayasari, "Evaluasi Program Gerakan 1000 Hari Pertama Kehidupan (HPK) Dalam Pencegahan Stunting Di Wilayah Kerja Puskesmas Jelbuk Kabupaten Jember Tahun 2018," Universitas Jember, 2019.

[7] G. Muthia and E. Yantri, "Evaluasi Pelaksanaan Program Pencegahan Stunting Ditinjau dari Intervensi Gizi Spesifik Gerakan 1000 HPK Di Puskesmas Pegang Baru Kabupaten Pasaman," J. Kesehat. Andalas, vol. 8, no. 4, pp. 100-108, 2019.

[8] N. Nefy, N. I. Lipoeto, and Edison, "Implementasi Gerakan 1000 Hari Pertama Kehidupan Di Kabupaten Pasaman 2017," Media Gizi Indones., vol. 14, no. 2, pp. 186-196, 2019.

[9] A. Ulansari, S. Amini, and S. Mulyati, "Sistem Pendukung Keputusan Gizi Balita Menggunakan Metode Simple Additive Weighting Berbasis Web," Proceeding SINTAK 2019, pp. 435-442, 2019.

[10] K. E. Kusuma and Nuryanto, "Faktor Risiko Kejadian Stunting Pada Anak Usia 2-3 Tahun (Studi di Kecamatan Semarang Timur)," J. Nutr. Coll., vol. 2, no. 4, pp. 523-530, 2013.

[11] N. Fenske, J. Burns, T. Hothorn, and E. A. Rehfuess, "Understanding child stunting in India: A 
comprehensive analysis of socio-economic, nutritional and environmental determinants using additive quantile regression," PLoS One, vol. 8, no. $11,2013$.

[12] W. Lestari, L. Kristiana, and A. Paramita, "Stunting: Studi Konstruksi Sosial Masyarakat Perdesaan Dan Perkotaan Terkait Gizi Dan Pola Pengasuhan Balita di Kabupaten Jember," Aspir. J. Masal. Sos., vol. 9, no. 1, pp. 17-33, 2018.

[13] R. Paudel, B. Pradhan, R. R. Wagle, D. P. Pahari, and S. R. Onta, "Risk Factors for Stunting Among Children: A Community Based Case Control Study in Nepal," Kathmandu Univ. Med. J., vol. 10, no. 39, pp. 18-24, 2012.

[14] G. Danaei et al., "Risk Factors for Childhood Stunting in 137 Developing Countries: A Comparative Risk Assessment Analysis at Global, Regional, and Country Levels," PLoS Med., vol. 13, no. 11, pp. 1-18, 2016.

[15] I. O. Senbanjo, K. A. Oshikoya, O. O. Odusanya, and O. F. Njokanma, "Prevalence of and Risk factors for Stunting among School Children and Adolescents in Abeokuta, Southwest Nigeria," $J$. Heal. Popul. Nutr., vol. 29, no. 4, pp. 364-370, 2011.

[16] R. Martorell and M. F. Young, "Patterns of stunting and wasting: Potential explanatory factors," $A d v$. Nutr., vol. 3, no. 2, pp. 227-233, 2012.

[17] K. G. Dewey and K. Begum, "Long-term consequences of stunting in early life," Maternal and Child Nutrition, vol. 7, no. SUPPL. 3. pp. 5-18, 2011.

[18] J. H. Rah, A. A. Cronin, B. Badgaiyan, V. Aguayo, S. Coates, and S. Ahmed, "Household sanitation and personal hygiene practices are associated with child stunting in rural India: A cross-sectional analysis of surveys," BMJ Open, vol. 5, no. 2, 2015.

[19] T. Fikadu, S. Assegid, and L. Dube, "Factors associated with stunting among children of age 24 to 59 months in Meskan district, Gurage Zone, South Ethiopia a case-control study," BMC Public Health, vol. 9, no. 4, pp. 1-7, 2009.

[20] H. Torlesse, A. A. Cronin, S. K. Sebayang, and R. Nandy, "Determinants of stunting in Indonesian children: Evidence from a cross-sectional survey indicate a prominent role for the water, sanitation and hygiene sector in stunting reduction," $B M C$ Public Health, vol. 16, no. 1, pp. 1-11, 2016.

[21] M. T. Ruel, Addressing the underlying determinants of undernutrition: Examples of successful integration of nutrition in poverty-reduction and agriculture strategies, vol. 36, no. 1564-3743. 2008.
[22] S. Arikunto, Prosedur Penelitian. Jakarta: Rineka Cipta, 2019.

[23] E. Yuliani, Immawanti, J. Yunding, Irfan, M. Haerianti, and Nurpadila, "Pelatihan Kader Kesehatan Deteksi Dini Stunting Pada Balita Di Desa Betteng (Health Cadre Training About Early Detection Of Stunting Toddler In Betteng Village )," J. Kesehat. Masy., vol. 01, pp. 41-46, 2018.

[24] F. D. Davis, "Perceived usefulness, perceived ease of use, and user acceptance of information technology," MIS Q Manag Inf Syst, vol. 13, no. 3, pp. 319-340, 1989.

[25] E. Noviarni, "Analisis Adopsi Layanan Internet Banking oleh Nasabah Perbankan di Pekanbaru," $J$. Al-Iqtishad, vol. I, pp. 27-40, 2014.

[26] W. V. Trisna, S. E. Daniati, and T. P. Sari, "Evaluasi Penggunaan Aplikasi Primary Care (P-CARE) BPJS Terhadap Pelayanan Kesehatan Di Puskesmas Se-Kota Pekanbaru Dengan Menggunakan Metode Technology Acceptance Model (TAM)," J. Inf. Technol. Comput. Sci., vol. 3, no. 2, pp. 152-161, 2020.

[27] E. Saputra and Misfariyan, "Analisis Penerimaan Sistem Informasi Manajemen Rumah Sakit Umum Daerah Bangkinang Menggunakan Metode Technology Acceptance Model (TAM)," J. Sains dan Teknol. Ind., vol. 10, no. 2, pp. 1-7, 2013.

[28] D. A. Adams, R. Nelson, P. A. Todd, and R. R. Nelson, "Perceived Usefulness, Ease of Use, and Usage of Information Technology: A Replication Increasing Systems Usage Perceived Usefulness, Ease of Use, and Usage of Information Technology: A Replication," Source MIS Q., vol. 16, no. 2, pp 227-247, 1992.

[29] R. L. Thompson, C. A. Higgins, and J. M. Howell, "Personal computing: Toward a conceptual model of utilization," MIS Q. Manag. Inf. Syst., vol. 15, no. 1, pp. 125-142, 1991.

[30] W. W. Chin and P. A. Todd, "On the use, usefulness, and ease of use of structural equation modeling in mis research: A note of caution," MIS Q. Manag. Inf. Syst., vol. 19, no. 2, pp. 237-246, 1995.

[31] I. Ajzen and M. Fishbein, The Influence of Attitudes on Behavior. 2021.

[32] M. Fishbein and I. Ajzen, Predicting and Changing Behavior. New York: Taylor \& Francis Group, 2010.

[33] R. Aditya and A. Wardhana, "Pengaruh perceived usefulness dan perceived ease of use terhadap behavioral intention dengan pendekatan Technology Acceptance Model (TAM) pada pengguna Instant Messaging LINE di Indonesia," J. Siasat Bisnis, vol. 20, no. 1, pp. 24-32, 2016. 
[34] N. Tangke, “Analisa Penerimaan Penerapan Teknik Audit Berbantuan Komputer (TABK) Dengan Menggunakan Technology Acceptance Model (TAM) Pada Badan Pemeriksa Keuangan (BPK) RI," J. Akunt. dan Keuang., vol. 6, no. 1, pp. 10-28, 2004.

[35] A. A. Hanggono, S. R. Handayani, and H. Susilo, "Analisis Atas Praktek TAM (Technology Acceptance Model) Dalam Mendukung Bisnis Online Dengan Memanfaatkan Jejaring Sosial Instagram," J. Adm. Bisnis, vol. 26, no. 1, pp. 1-9, 2015. 